\title{
Response to There Are No Hard-to-Serve Learners, Only Ill-Served Ones by Erik Jacobson, Montclair State University
}

Joni Schwartz, City University of New York, LaGuardia Community College

A decade and a half ago, the community of adult educators to which I belonged called the phenomenon that Jacobson describes in There Are No Hard-to-Serve Learners as "creaming." This is the practice of choosing to serve certain students, in this case those with high scores on their initial $\mathrm{GED}^{\circledast}$ practice test or students with advanced $\mathrm{TABE}^{\varpi}$ scores, so that we fulfilled our performance objectives and more easily demonstrated employability. We knew what we were doing. The reasons were economic; we needed to show outcomes that would continue to make our adult education program eligible for funding.

As Jacobson states, “despite WIOA language explaining that variations in students' backgrounds will be accounted for in evaluations, some programs remain concerned about how the skill level of the students they enroll may impact their outcomes, and thus their funding." This was the concern in the instance with which I opened.

Whether this concern is fully founded or not, I agree with Jacobson that the labeling of individuals as hard to serve is unfortunate and misdirected in that it suggests that these students are somehow deficient and are the problem rather than identifying complex systemic issues that make some adult education programs necessary in the first place. To be more specific, how prepared an adult student is for employment at a living wage, career credentialing, acquiring a high school diploma or GED ${ }^{\oplus}$, or fluency in English is often dependent upon and intersected with civil rights issues of equality and equity. Systemically and institutionally, there is disproportional access to quality education, health care, and housing for people of color, the poor, and the immigrant. This disproportionality is often driven by race, class, and immigration policies.

Jacobson is right. Evaluation metrics should not solely measure individual employment placements, recidivism, or movement away from public assistance without accounting for how programs and policies support and provide access, opportunity, education toward equity. One simple example is the Restoring Education and Learning Act (REAL Act) which has bipartisan congressional support and, if passed, restores the PELL Grant in prison adult education programs. This is one common sense, cost effective, and systemic approach to outcomes putting the onus on institutional change (Grawert, 2019; Sangree, 2019).*

I am reminded of Ibram Kendi's distinction between an assimilationist and anti-racist 
approach to American issues of inequality and racism. Assimilationist's perspectives place the responsibility for poverty, employment, education difference, and racism on individuals and their need to improve and meet certain outcomes. Anti-racist perspectives challenge policies because policies construct and maintain inequalities; racist ideology follows (Kendi, 2016). Following Kendi's framework, labeling students hard to serve is assimilationist in nature, therefore decidedly racist. We, as adult educators, and those responsible for WIOA policy would do well to ponder. But I diverge.

Overall, I agree with Jacobson's predominant premise - words matter. And the use of the term hard to serve is at best misinformed and at worst harmful. I strongly agree with Jacobson, "Recognizing that there are no hard-to-serve students, only ill-served ones, will help clarify the political project required to remove the barriers that stand in these students' way." Language is a first step.

Unfortunately, Jacobson does make one error when referring to people formerly involved with the criminal justice system as "ex-offenders." Granted, this term is WIOA language, but Jacobson continues to use the term. Ex-offender like ex-inmate, ex-felon, or ex-con is inappropriate and pejorative, defining individuals by perhaps the worst moments in their lives. It is not the totality of who they are. Therefore, using identifiers such as a person who experienced the criminal justice system, person formerly in prison, or formerly incarcerated citizen is better. (Tranet al., 2018).

Why should this choice of words matter? As adult educators, we profess to be learner centered, and many of us come from the tradition of Freire and Mezirow with a deep investment in andragogy and transformative learning which begins with hearing from the adult learner. In the case of persons formerly incarcerated, we have heard their collective voices as articulated in the now famous 2007 Eddie Ellis language letter:

When we are not called mad dogs, animals, predators, offenders and other derogatory terms, we are referred to as inmates, convicts, prisoners and felons-all terms devoid of humanness which identify us as "things" rather than as people. These terms are accepted as the "official" language of the media, law enforcement, prison industrial complex and public policy agencies. However, they are no longer acceptable for us and we are asking people to stop using them. (Ellis, 2012)

From my reading of Jacobson's article, I think he would agree with the necessity for this personcentered language. In fact, this is exactly to his point, so it is a little surprising that he uses the pejorative term ex-offender.

One final addition to Jacobson's analysis of hardto-serve students is his reference to ESOL and why because someone is foreign born should that make them harder to serve. Jacobson raises an excellent question in that adult students who are fluent in one, two, three or sometimes more languages, especially if they are literate in their origin language, are frequently "easier" to teach than students who are monolingual.

The debated Sapir-Whorf hypothesis states that language shapes thought and perception and implies that speakers of different languages think and perceive reality in different ways; each language has its own world view (Hussein, 2012). And again, to Jacobson's point, speaking multiple languages enlarges our cognitive schemata cultivating more nuanced ways of seeing the world expanding vocabulary, larger frames of reference, and life experiences.

Recent neurological research has shown that learning a language may subtly change, and 
possibly improve, the way we think by expanding the brain's capacity. The benefits are quite clear for children but even for adults, bilingualism can postpone the onset of dementia and keep the brain agile (Bhattacharjee, 2012; Schlegel et al., 2012).

We as adult educators would do well to remember that not knowing English is not a liability but a difference; fluency in more than one language is an asset. Around the world, more than half of people - estimates vary from $60-75 \%$ - speak at least two languages. Many countries have more than one official national language where citizens speak multiple languages. In an increasingly global world with the ability to communicate cross culturally is a tremendous benefit. ESOL (and the term should be ESOL not ESL) students can hardly be considered hard to serve but rather well positioned to learn and contribute to an ever linguistically changing America.

The overarching thrust of Jacobson's article is well articulated and rings true. We need to "stress the specific nature of oppressions some learners face ... change the terminology we use, ... call attention to the ways in which some adult learners are disempowered and help prioritize systemic change."

\footnotetext{
* Since the writing of this article restoration of the PELL Grant to prisoners has been included in the December 2020, COVID/Stimulus Bill.
} 


\section{References}

Bhattacharjee, Y. (2012, March). Why bilinguals are smarter. The New York Times. https://www.nytimes. com/2012/03/18/opinion/sunday/the-benefits-ofbilingualism.html

Ellis, E. $(2012 ; 2007)$. An open letter to our friends on the question of language. Parole Preparation, 5. https:// ir.lawnet.fordham.edu/pp/5

Grawert, A. C. (2019). The legal case for education in prison. In G. Robinson \& E. English Smith (Eds), Education for liberation: The politics of promise and reform inside and beyond America's prisons (pp. 7796). Rowman \& Littlefield.

Hussein, B. (2012). The Saphir-Whorf hypothesis today. Theory and Practice in Language Studies, 2(3), 642-646.

Kendi, I. X. (2016). Stamped from the beginning: The definitive history of racist ideas in America. Nation Books.
Sangree, R. (March 2019). Congress should reinstate Pell Grants for incarcerated students. Brennan Center for Justice. https://www.brennancenter.org/our-work/ analysis-opinion/congress-should-reinstate-pell-grantsincarcerated-students

Schlegel, A., Rudelson, J. \& Tse, P. (2012). White matter structure changes as adults learn a second language. Journal of Cognitive Neuroscience, 24(8), 1664-1670.

Tran, N.T., Baggio, S., Dawson, A., O’Moore, E., Williams, B., Bedell, P., Simon, O., Scholten, W., Getaz, L., \& Wolff, H. (2018). Words matter: a call for humanizing and respectful language to describe people who experience incarceration. BMC International Health and Human Rights, 18(41), https://doi.org/10.1186/ s12914-018-0180-4 